\title{
Ectopic connection of left coronary artery from right coronary sinus, is the treatment always surgical?
}

\author{
Ahmed Sghaier, Nejeh Ben Halima, Houssem Thabet
}

Cardiology Department, Ibn El Jazzar University Hospital - Kairouan, Tunisia

ARTICLE INFO

Article history:

Submitted: 18. 2. 2021

Revised: 21. 3. 2021

Accepted: 3. 4. 2021

Available online: 5. 10. 2021

\section{Klíčová slova:}

Anomální anatomie

koronárních tepen

Bolest na hrudi

Městnavé srdeční selhání

Náhlá smrt
SOUHRN

Kontext: S anomálním odstupem kmene levé koronární tepny z protilehlého sinu (anomalous left coronary artery aortic origin from the right sinus, ALCA) se Ize setkat vzácně. Anomální odstup koronárních tepen (anomalous origin of coronary arteries, AOCA) představuje druhou nejčastější přičinu náhlé srdeční smrti mladých sportovců v USA. Léčba těchto anomálií je předmětem sporu a dosud nebyla vypracována doporučení pro stratifikaci rizika.

Kazuistika: Pětačtyřicetiletý muž bez kardiovaskulárních rizikových faktorů byl přijat do naší nemocnice pro svíravou, silnou bolest za hrudní kostí během intenzivní fyzické aktivity. Jeho vitální známky byly normální. Výsledek EKG vyšetření byl normální a laboratorní vyšetření odhalilo vysoké hodnoty troponinů. Echokardiogram prokázal nedilatovanou levou komoru srdeční se zachovanou ejekční frakcí levé komory. Koronarografie zjistila abnormální odstup levé věnčité tepny z pravého koronárního sinu bez významné stenózy a vyšetření koronárních tepen výpočetní tomografií prokázalo preaortální počáteční průběh levého kmene věnčité tepny. Zátěžové scintigrafické vyšetření myokardu neprokázalo reziduální ischemii. U pacienta byla zahájena nefarmakologická léčba formou úpravy životosprávy a pravidelného monitorování srdeční funkce. Při kontrole po jednom roce byl pacient naprosto bez symptomů.

Závěr: S anomálním odstupem kmene levé koronární tepny z protilehlého sinu se Ize setkat velice zřídka, vzhledem k vyššímu riziku srdečních příhod je však nutno mít tuto možnost na paměti. $\mathrm{K}$ přesnějšímu zjištění spojení a počátečního průběhu Ize použít zobrazovací techniky. Rozhodování o tom, zda usilovat či neusilovat o korekci ALCA, je i nadále obtížné. Naše př́pady byly řešeny odlišně, přičemž úspěšné dlouhodobé sledování prokázalo, že léčbu je nutno individualizovat a ideálně posoudit poměr prínosu a rizik samostatně pro každého jednotlivého pacienta.

(c) 2021, ČKS.

\section{ABSTRACT}

Background: Anomalous left coronary artery aortic origin from the right sinus (ALCA) is rare. Anomalous origin of coronary arteries (AOCA) is the second leading cause of cardiac death among young athletes in the US. Their management remains controversial and there are still no pre-established recommendations for risk stratification.

Case presentation: A 45-year-old male with no cardiovascular risk factors, was admitted to our hospital for constrictive, intense, retrosternal chest pain during intense activities. His vital signs were normal. ECG was normal and biology revealed high troponin levels.

Echocardiogram revealed a non-dilated left ventricle with a preserved left ventricle ejection fraction. Coronary artery angiography showed an abnormal left coronary artery origin from the right coronary sinus with no significant coronary stenosis and coronary computed tomography described a pre-aortic initial course of the left main artery.

Stress myocardial scintigraphy did not show residual ischemia. The patient was medically treated with changes in his lifestyle and regular monitoring. A one-year follow-up showed a perfectly asymptomatic patient.

Keywords:

Chest pain

Congenital heart disease

Coronary anomaly

Sudden death is possible to use imaging techniques to better analyze the connection and the initial course. The decision to correct surgically or not to correct an ALCA remains difficult. Our cases were treated differently, with satisfactory long-term follow-up showing that the treatment should be individualized with a benefit/risk ratio assessed preferentially for each patient separately. 


\section{Background}

Anomalous aortic origin of the coronary arteries (AOCA) are still a challenge in the field of cardiology. Often accidentally discovered, their incidence is estimated at $1.2 \%$ of the general population., ${ }^{1,2}$ This pathology grows in view of the risk of sudden death associated mainly with left coronary artery originating from the right sinus.

Despite decades of research, we still have a limited understanding of the mechanisms of sudden death and there is incomplete data on risk stratification and management.

\section{Case presentation}

A 45-year-old male, was admitted to our hospital for chest pain. His history noted no diabetes, no hypertension and no active smoking.

The patient described the pain as constrictive, intense, retrosternal chest pain during intense activities during 3 to 5 minutes and disappearing at rest.

His vital signs at presentation were as follows: blood pressure at 130/65 $\mathrm{mmHg}$, heart rate at 90 b.p.m. and respiratory rate of 18 cycles/min. Lung sounds were normal; and there were no signs of heart failure.

ECG was normal and biology revealed high troponin levels at $0.1 \mathrm{ng} / \mathrm{ml}$. The rest of the results were normal.

The patient was therefore hospitalized.

Echocardiogram revealed a non-dilated left ventricle (LV) with a preserved left ventricular ejection fraction (LVEF) at 55\%. Left coronary artery birth anomaly was also seen (Fig.1).

Coronary artery angiography showed an abnormal left coronary artery departure from the right coronary sinus with no significant coronary stenosis (Fig. 2).

A coronary computed tomography scan (Figs 3-5) confirmed the diagnosis and described a pre-aortic initial course of the left main artery.

Stress myocardial scintigraphy did not show residual ischemia. The patient was put on aspirin, beta-blockers and isosorbide dinitrate with changes in his lifestyle and regular monitoring.

A one year follow-up showed a perfectly asymptomatic patient.

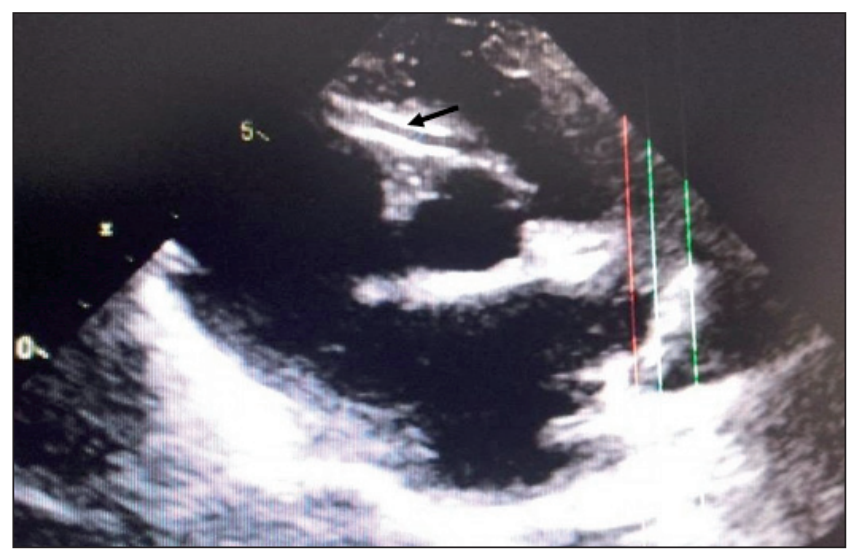

Fig. 1 - TTE showing a left coronary artery of ectopic birth.

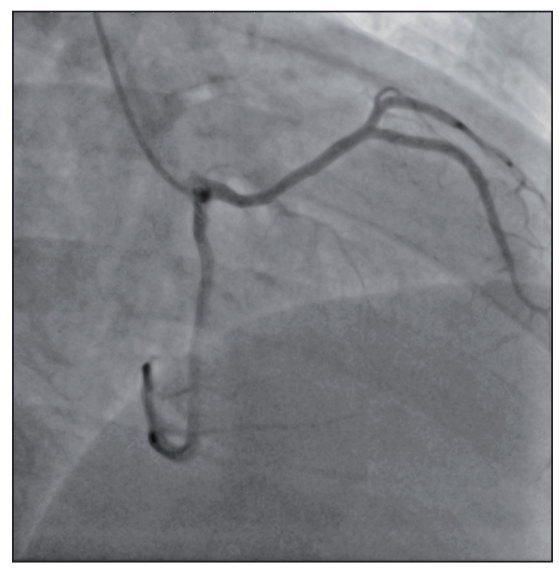

Fig. 2 - Angiographic image of the left coronary artery arising from the right sinus.
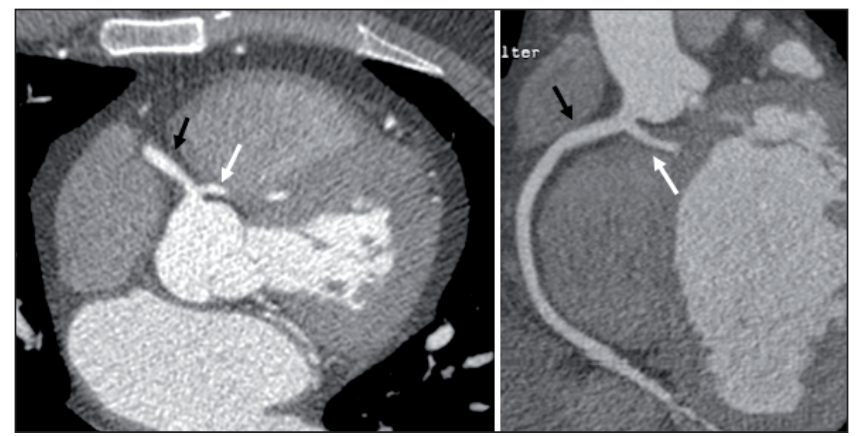

Fig. 3 - Coronary computed tomography: Axial and coronary tomographic images of an ectopic connection of the left coronary artery (white arrow) in the anterolateral sinus, close to the birth of the right coronary artery (black arrow).
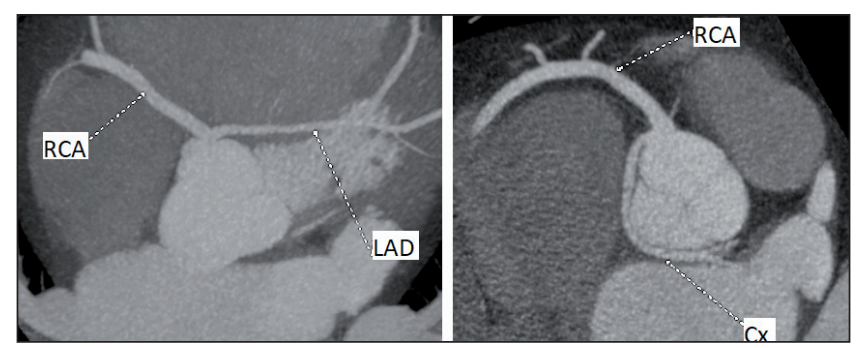

Fig. 4 - Coronary computed tomography: Axial images of an ectopic connection of the left coronary artery in the anterolateral sinus, close to the birth of the right coronary artery. $\mathrm{Cx}$ - circumflex artery; LAD - left descending artery; RCA - right coronary artery,
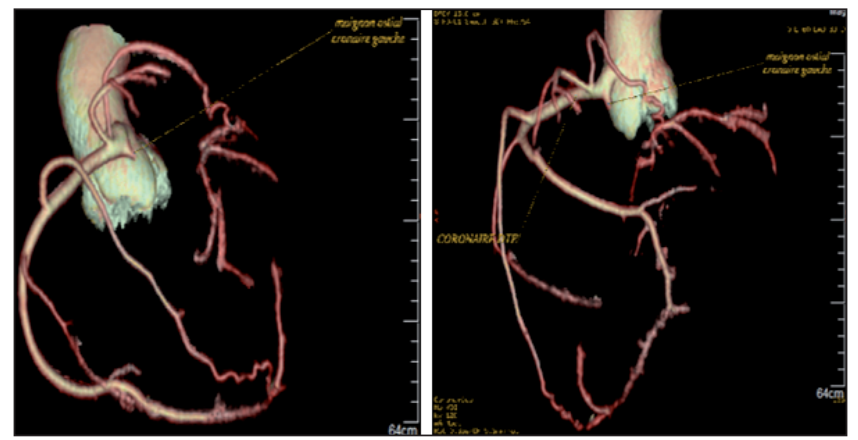

Fig. 5 - Coronary computed tomography: 3D images showing the ostial stump of the left coronary artery from the right coronary sinus and its pre-aortic initial course. 


\section{Discussion}

Although incidence and natural history of anomalous aortic origin of the coronary arteries (AOCA) are difficult to determine, it is estimated to range from 0.6 to $1.2 \%$ of the general population according to large angiographic studies. ${ }^{1,2}$ In a Tunisian study, we found it at $0.27 \% .{ }^{3}$ But these series are likely to underestimate the true incidence as many people never undergo coronary angiography. The abnormal origin of the left coronary artery from the right sinus (ALCA) is quite rare (with an estimated incidence of $0.03-0.05 \%)$, ${ }^{4-12}$ it is the second most common cause of cardiac death among young athletes in the United States. ${ }^{13}$

Basso et al. ${ }^{14}$ examined 2 large registries in the United States and Italy reporting sudden cardiovascular death in young competitive athletes over a period of 10 to 20 years. Twenty-seven deaths were recorded in patients who had no symptoms, 14 patients had ALCA. It is mostly the anomalous aortic origin of the left coronary artery that is often associated with early sudden death, especially during vigorous exercise.

The symptoms are usually absent in everyday life. The most common mode of discovery remains a "recovered" sudden death, occurring while or immediately after a very intense physical effort. Sometimes warning signs prior to the acute episode exist such as: chest pain, syncope, or cardiac arrhythmia during exercise. Increasingly, the anomaly is detected during an echocardiographic assessment performed for another cardiovascular reason..$^{15}$

Sudden death can result from one or more mechanisms that compromise coronary blood flow. Several episodes of ischemia are probably necessary creating a substrate for the catastrophic event. ${ }^{14}$ Although there is no clear consensus on the mechanism of ischemia and the risk factors leading to sudden death in these patients. ${ }^{16}$ It has been suggested that this risk is increased in young patients (< 35 years) with an abnormal left coronary artery origin, after intense physical activity, and in the presence of some anatomical features summarized in: an inter-aortopulmonary course, an intra-mural aortic course, a slit-like ostium and an acute angle of the coronary artery departure from the aorta. ${ }^{17,18} \mathrm{~A}$ number of studies have been conducted attempting to isolate a key factor, but no single component of coronary artery anatomy has been identified as the definitive cause of ischemia. A slit-like ostium and a narrow intramural course might be the most involved, but absolute proof has not yet been advanced. ${ }^{19}$

Atherosclerotic disease has not been described in these abnormalities. ${ }^{1}$ In the absence of revealing symptoms, the diagnosis can be made on a variety of imaging modalities, including echocardiography, computed tomography (CT), magnetic resonance imaging (MRI) and cardiac catheterization, but a protocol of standard imaging has not been yet decided. ${ }^{2,19}$

Echocardiographic examination supports diagnosis, especially in children or adolescents. Technological advances in transthoracic echocardiography (TTE) now allow vision of coronary artery anatomy in many patients. The identification of the abnormal origin of the left coronary artery has been described using TTE. ${ }^{20-25}$ TTE in two- dimensional mode must often be combined with color Doppler to successfully identify the abnormal origin of a coronary artery. ${ }^{20}$ In adults, the diagnosis may be more difficult and any suspicion must be confirmed by an imaging technique (coronary angiography, CT scan or MRI). In asymptomatic patients, additional examinations are necessary to reveal an eventual on exertion ischemia (stress echocardiography or myocardial scintigraphy). ${ }^{15}$

The management of AOCA remains controversial. Although patients with symptoms of ischemia or arrhythmia are candidates for urgent management, decisions about asymptomatic patients are less well defined and there is still no pre-established consensus for risk stratification. ${ }^{26}$ Noninvasive functional imaging is commonly used to stratify risk and emerging data from invasive cardiac catheterization with intravascular ultrasound (IVUS) may be useful in a selected group of patients. ${ }^{27}$

The North American guidelines recommend surgical revascularization of all ALCAs with an inter aortopulmonary course, regardless of the existence of myocardial ischemia and age..$^{28}$

The top professional athletes must stop their activities and completely change their life goals. Other patients must change their lifestyle and accept a constant risk of sudden death from physical exertion. This can be difficult to bear in patients especially in teenagers and young adults. Behavior and psychosocial development can be severely impaired.

Our patient was medically treated, with satisfactory long-term follow-up, this shows that the treatment should be individualized with a benefit/risk ratio assessed preferentially for each patient apart.

\section{Conclusion}

AAOCA is a rare anomaly but is gaining more and more importance in current cardiac practice given the high risk and difficulty in assessing sudden death in young and athletic patients. Despite decades of research, we still have a limited understanding of the mechanisms of sudden death and there is incomplete data on risk stratification. The ideal treatment does not yet exist and a case by case management is necessary.

\section{Acknowledgements}

None.

\section{Conflicts of interest}

The authors declare that they have no competing interests.

\section{Funding body}

No funding was received.

\section{Ethical statement and consent to participate Not applicable.}

\section{Consent for publication}

Written informed consent was obtained from the patient for publication of this case report and accompanying images. 


\section{Availability of data and materials \\ Available upon request.}

\section{References}

1. Topas O, DeMarchena EJ, Perin E, et al. Anomalous coronary arteries: angiographic findings in 80 patients. Int J Cardiol 1992;34:129-138.

2. Yamanaka O, Hobbs RE. Coronary artery anomalies in 126,595 patients undergoing coronary arteriography. Cathet Cardiovasc Diagn 1990;21:28-40.

3. Ouali S, Neffeti E, Sendid K, et al. Congenital anomalous aortic origins of the coronary arteries in adults: a Tunisian coronary arteriography study. Arch Cardiovasc Dis 2009;102:201-208.

4. Liberthson RR, Dinsmore RE, Fallon JT. Aberrant coronary artery origin from the aorta: report of 18 patients, review of literature and delineation of natural history and management. Circulation 1979;59:748-754.

5. Roberts WC. Major anomalies of coronary arterial origin seen in adulthood. Am Heart J 1986;111:941-963.

6. Frescura C, Basso C, Thiene G, et al. Anomalous origin of coronary arteries and risk of sudden death: a study based on an autopsy population of congenital heart disease. Hum Pathol 1998;29:689-695.

7. Taylor AJ, Rogan KM, Virmani R. Sudden cardiac death associated with isolated congenital coronary artery anomalies. J Am Coll Cardiol 1992;20:640-647.

8. Lipsett J, Byard RW, Carpenter BF, et al. Anomalous coronary arteries arising from the aorta associated with sudden death in infancy and early childhood. Arch Pathol Lab Med 1991;115:770-773.

9. Kragel $\mathrm{AH}$, Roberts WC. Anomalous origin of either the right or left main coronary artery from the aorta with subsequent coursing between aorta and pulmonary trunk: analysis of 32 necropsy cases. Am J Cardiol 1988;62:771-777.

10. Herrmann MA, Dousa MK, Edwards WD. Sudden infant death with anomalous origin of the left coronary artery. Am J Forensic Med Pathol 1992;13:191-195.

11. Roberts WC, Shirani J. The four subtypes of anomalous origin of the left main coronary artery from the right aortic sinus (or from the right coronary artery). Am J Cardiol 1992;70:119-121.

12. Barth CW, Roberts WC. Left main coronary artery originating from the right sinus of Valsalva and coursing between the aorta and pulmonary trunk. J Am Coll Cardiol 1986;7:366-373.

13. Brothers J, Gaynor JW, Paridon S, et al. Anomalous aortic origin of a coronary artery with an interatrial course: understanding current management strategies in children and young adults. Pediatr Cardiol 2009;30:911-921.

14. Basso C, Maron BJ, Corrado D, Thiene G. Clinical profile of congenital coronary artery anomalies with origin from the wrong aortic sinus leading to sudden death in young competitive athletes. J Am Coll Cardiol 2000;35:1493-1501.

15. Vouhé PR. Anomalous aortic origin of coronary arteries: a frequent and curable cause of sudden death. Bulletin de L'Academie Nationale de Medecine 2015;198:465-470.
16. Maron BJ, Doerer JJ, Haas TS, et al. Sudden deaths in young competitive athletes: analysis of 1866 deaths in the United States, 1980-2006. Circulation. 2009;119:1085-1092.

17. Vouhé PR. Anomalous aortic origin of a coronary artery is always a surgical disease. Semin Thorac Cardiovasc Surg Pediatr Card Surg Annu 2016;19:25-29.

18. Taylor AJ, Byers JP, Cheitlin MD, Virmani R. Anomalous right or left coronary artery from the contralateral coronary sinus: "high-risk" abnormalities in the initial coronary artery course and heterogeneous clinical outcomes. Am Heart J 1997;133:428-435.

19. Kardos A, Balsai L, Rudas L, et al. Epidemiology of congenital coronary artery anomalies: a coronary arteriographic study on a Central European population. Cathet Cardiovasc Diagn 1997;42:270-275.

20. Frommelt PC, Berger S, Pelech AN, et al. Prospective identification of anomalous origin of left coronary artery from the right sinus of Valsalva using transthoracic echocardiography: importance of color Doppler flow mapping. Pediatr Cardiol 2001;22:327-332.

21. Stefanelli CB, Stevenson JG, Jones TK, et al. A case for routine screening of coronary artery origins during echocardiography: fortuitous discovery of a life-threatening coronary anomaly. J Am Soc Echocardiogr 1999;12:769-772.

22. Nowak B, Voigtlander $T$, Jolsch B, et al. Echocardiographic visualization of anomalous left main coronary arteries originating from the right sinus of Valsalva. Int J Cardiol 1994;46:67-73.

23. Daliento L, Gasoli G, Mazzucco A. Anomalous origin of the left coronary artery from the anterior aortic sinus: role of echocardiography. Int J Cardiol 1993;38:89-91.

24. Zeppilli $P$, dello Russo A, Santini $C$, et al. In vivo detection of coronary artery anomalies in asymptomatic athletes by echocardiographic screening. Chest 1998;114:89-93.

25. Maron BJ, Leon MB, Swain JA, et al. Prospective identification by two-dimensional echocardiography of anomalous origin of the left main coronary artery from the right sinus of Valsalva. Am J Cardiol 1991;68:140-142.

26. Welton M. Management of Anomalous Coronary Artery From the Contralateral Coronary Sinus. J Amer Coll Cardiol 2007;50:2083-2084.

27. Molossi S, Agrawal H. Coronary artery anomalies: A multidisciplinary approach to shape the landscape of a challenging problem. Congenit Heart Dis 2017;12:596.

28. Warnes $C$, Williams $R$, Bashore $T$, et al. ACC/AHA 2008 guidelines for the management of adults with congenital heart disease: a report of the American College of Cardiology/American Heart Association Task Force on Practice Guidelines (Writing Committee to Develop Guidelines on the Management of Adults With CongenitalHeart Disease). Developed in collaboration with the American Society of Echocardiography, Heart Rhythm Society, International Society for Adult Congenital Heart Disease, Society for Cardiovascular Angiography and Interventions, and Society of Thoracic Surgeons. J Am Coll Cardiol 2008;52:e143-e263. 